\title{
PERJANJIAN DALAM PERKAWINAN MENURUT PUTUSAN \\ MAHKAMAH KONSTITUSI RI NO. 69/PUU-XIII/2015 DAN \\ PENETAPAN PENGADILAN NEGERI TANGERANG \\ NO.269/PEN.PDT.P/2015/PN.TNG
}

\author{
Veren Abigail \\ (Mahasiswa Program S1 Fakultas Hukum Universitas Tarumanagara) \\ (abigailveren@gmail.com)
}

Prof. Dr. Abdul Gani Abdullah, S.H., LL.M

(Corresponding Author)

\begin{abstract}
(Dosen Fakultas Hukum Universitas Tarumanagara. Meraih Sarjana Hukum pada Fakultas Hukum Universitas Islam Jakarta, Doktor (Dr.) pada Fakultas Teknologi Kependidikan Universitas Islam Negeri Syarif Hidayatullah Jakarta)
\end{abstract}

\begin{abstract}
According to the Marriage Law Article 29 the marriage agreement is made before or at the time of marriage. But in October 2016 the Constitutional Court passed verdict No.69 / PUU-XIII / 2015 as a material test of Article 29 of the Marriage Law which with the ruling of the constitutional court the marriage agreement can be made before, at the time of marriage, even throughout the marriage. However, before the constitutional court issued the verdict, the Tangerang District Court issued a ruling stipulating the marriage agreement throughout the marriage, namely the decision No. 269 / PEN.PDT.P / 2015 / PN.TNG which the parties were mixed marriages couple. The problem discussed is what the judge considers in deciding the marriage agreement when there is no provision that the marriage agreement can be made throughout the marriage. The legal research method used is a normative research method. Based on the research's result, the judge granted and stipulated the marriage agreement based on the Marriage Law Article 4 which states that the marriage agreement is possible to be changed as long as there is agreement between the two parties and does not harm the third party In conclusion, the judge did not decide in accordance with the law regulating at the time. The suggestion is that it is expected that the judge as a law enforcer can make a decision in accordance with the law regulating at that time. Because ideally the judge's decision must contain justice, legal certainty, and expediency.
\end{abstract}

Keywords: Marriage Law, Marriage Agreement. 
Veren Abigail \& Abdul Gani Abdullah PERJANJIAN DALAM PERKAWINAN MENURUT PUTUSAN MAHKAMAH KONSTITUSI RI NO. 69/PUU-XIII/2015 DAN

PENETAPAN PENGADILAN NEGERI TANGERANG NO.269/PEN.PDT.P/2015/PN.TNG

\section{PENDAHULUAN}

\section{A. Latar Belakang}

Perkawinan adalah suatu proses hidup dan suatu proses hukum yang akan dilalui oleh banyak kalangan masyarakat, perkawinan sendiri merupakan suatu proses yang sakramental, suci dan kudus. Perkawinan tersebut juga harus dilandasi dengan kasih dan rasa hormat di antara kedua calon mempelai. Dalam Undang-Undang Dasar 1945 dalam Pasal 28B dikatakan setiap orang berhak membentuk keluarga dan melanjutkan keturunan melalui perkawinan yang sah.

Perkawinan tentunya juga diatur di dalam suatu Undang-Undang yaitu Undang-Undang Nomor 1 Tahun 1974 tentang Perkawinan (UU Perkawinan), dalam Pasal 1 menyatakan bahwa perkawinan adalah ikatan lahir batin antara seorang pria dan wanita sebagai suami istri dengan tujuan membentuk keluarga yang bahagia dan kekal berdasarkan Ketuhanan Yang Maha Esa.

Perkawinan merupakan suatu proses atau kejadian sakral di dalam hidup manusia. Perkawinan ini dapat dikatakan sebagai bentuk untuk mengesahkan hubungan diantara laki-laki dengan perempuan. Menurut UU Perkawinan, perkawinan adalah ikatan lahir batin antara seorang pria dan seorang wanita sebagai sepasang suami isteri yang bertujuan membentuk keluarga atau rumah tangga yang dibangun dengan keinginan agar perkawinan tersebut berjalan dengan bahagia dan kekal berdasarkan Ketuhanan Yang Maha Esa."1 Disebuah perkawinan tujuan yang hendak dicapai selain untuk memenuhi kebutuhan biologis dan keinginan duniawi tetapi lebih dari sekedar itu, yaitu suatu ikatan secara batin dan lahir diantara seorang pria dan wanita sebagai pasangan suami istri yang sudah bukan lagi dua melainkan satu secara sah dimana hukum dan agama.

\footnotetext{
${ }^{1}$ Indonesia, Undang-undang Nomor 1 Tahun 1974 tentang Perkawinan (Lembar Negara Republik Indonesia Tahun 1974 Nomor 1, Tambahan Lembar Negara Republik Indonesia Nomor 3019), Pasal 29.
} 
Veren Abigail \& Abdul Gani Abdullah PERJANJIAN DALAM PERKAWINAN MENURUT PUTUSAN MAHKAMAH KONSTITUSI RI NO. 69/PUU-XIII/2015 DAN

PENETAPAN PENGADILAN NEGERI TANGERANG NO.269/PEN.PDT.P/2015/PN.TNG

Terhadap urusan pencampuran harta bersama didalam rumah tangga tidak jarang dapat menimbulkan permasalahan bahkan menimbulkan perselisihan. Terlebih jika perkawinan tersebut adalah perkawinan campuran maka akan ada beberapa hal yang timbul dikarenakan perbedaan kewarganegaraan tersebut. Misalnya, Warga Negara Indonesia (WNI) yang menikah dengan Warga Negara Asing (WNA) itu tidak diperbolehkan untuk memiliki hak atas tanah yang berupa: Hak Milik, Hak Guna Bangunan (HGB) ataupun Hak Guna Usaha (HGU). Hal tersebut sesuai dengan ketentuan yang ada didalam Pasal 35 UU Perkawinan yang menyatakan bahwaseluruh harta benda jika didapat disepanjang perkawinan akan secara langsung menjadi harta milik bersama suami dan istri tersebut. Dengan demikian, akan terjadi adanya pencampuran harta antara pasangan WNI dengan WNA tersebut. Sedangkan, sesuai dengan ketentuan dalam "Undang-Undang Nomor 5 Tahun 1960 tentang Peraturan Dasar PokokPokok Agraria (UUPA)" mengatakan bahwa seorang WNA tidak diperbolehkan memiliki Hak Milik, Hak Guna Usaha, dan Hak Guna Bangunan. Hal tersebut dimana dinyatakan didalam Pasal 21 ayat (1) yang mengatakan bahwa yang dapat memiliki hak milik hanyalah warga negara indonesia saja. Di dalam pasal 30 ayat (1)a juga dikatakan bahwa yang diperbolehkan memiliki Hak Guna Usaha adalah warga negara indonesia dan dalam pasal 36 ayat (1)a menyatakan bahwa yang dapat mempunyai Hak Guna Bangunan adalah seorang warga negara Indonesia.

Hal-hal tersebut dapat menyimpulkan bahwa pasangan suami isteri WNI dengan WNA dengan pencampuran harta perkawinan tidak diperkenankan untuk memiliki Hak Milik, Hak Guna Usaha, dan Hak Guna Bangunan. Jika pasangan perkawinan campuran ingin memiliki ketiga hak tersebut, pasangan suami isteri tersebut diharuskan untuk membuat Perjanjian Perkawinan.

Melihat contoh permasalahan diatas, maka seiring berkembangnya zaman seperti sekarang ini, akan banyak calon pasangan suami istri yang 
Veren Abigail \& Abdul Gani Abdullah

membuat perjanjian perkawinan tersebut karena perjanjian perkawinan dilihat perlu dan dibutuhkan di dalam urusan rumah tangga diantara suami dan istri saat itu juga maupun dikemudian hari. Perjanjian perkawinan (Prenuptial Agreement) ialah perjanjian atau persetujuan yang dibuat oleh sepasang calon suami istri sebelum perkawinan atau pada saat perkawinan dilangsungkan yang bertujuan untuk mengatur beberapa akibat perkawinan yang berdampak kepada harta kekayaan mereka didalam perkawinan mereka nanti. ${ }^{2}$ Perjanjian perkawinan adalah sah dimata hukum Indonesia. Namun, terdapat beberapa aturan yang harus diperhatikan dalam membuat Perjanjian Perkawinan, mulai dari waktu yang diperbolehkan untuk perjanjian perkawinan itu dibuat, sejak saat apa perjanjian perkawinan itu berlaku, hal apa saja yang dapat ditentukan di dalam perjanjian perkawinan tersebut, sampai kepada ketentuan-ketentuan mengenai perubahan perjanjian perkawinan jika dibutuhkan dikemudian hari.

Kitab Undang-Undang Hukum Perdata (KUH Perdata) mengatur tentang perjanjian kawin, namun dialamnya tidak satupun dari pasal-pasal tersebut ada yang menjelaskan definisi dari perjanjian perkawinan itu sendiri, hanya menurut KUH Perdata, Perjanjian Perkawinan dapat diartikan sebagai suatu penyimpangan terhadap ketentuan mengenai harta kekayaan atau milik bersama yang sebelumnya diatur oleh KUH Perdata. Hal tersebut sesuai dengan isi dalam Pasal 139 yang menyatakan bahwa jika calon pasangan suami istri hendak membuat perjanjian perkawinan maha pasangan calon suami istri tersebut diperbolehkan mengenyampingkan aturan mengenai harta bersama yang sebelumnya sudah diatur didalam UU selama penyimpangan terseubt tidak keluar dari norma-norma yang baik yang diemban didalam masyarakat.

Hal itu tentu tidak sama dengan yang diatur didalam "UU Perkawinan", perjanjian perkawinan diatur dalam Pasal 29 yang berbunyi:

\footnotetext{
${ }^{2}$ R. Soetojo Prawirohamidjojo, Hukum Orang dan Keluarga, (Surabaya: Alumni, 2000), 57.
} 
1. Pada waktu atau sebelum perkawinan berlangsung, kedua pihak atas persetujuan bersama dapat mengadakan perjanjian tertulis yang disahkan oleh pegawai pencatat perkawinan, setelah mana isinya berlaku juga terhadap pihak ketiga sepanjang pihak ketiga tersangkut.

2. Perjanjian tersebut tidak dapat disahkan bilamana melanggar batas-batas hukum, agama dan kesusilaan.

3. Perjanjian tersebut berlaku sejak perkawinan dilangsungkan.

4. Selama perkawinan berlangsung perjanjian tersebut tidak dapat diubah, kecuali bila dari kedua pihak ada persetujuan untuk merubah dan perubahan tidak merugikan pihak ketiga. ${ }^{3}$

Setelah dijabarkan demikian apa yang dikatakan oleh UU Perkawinan tersebut diatas, maka dapat disimpulkan bahwa perjanjian kawin hanya diperbolehkan untuk dibuat pada saat perkawinan berlangsung atau sebelum perkawinan berlangsung dengan sepengetahuan dan disetujui oleh kedua pihak dan disahkan oleh pihak yang berwenang, yaitu adalah pegawai pencatat perkawinan yang juga isi perjanjian tersebut berlaku juga terhadap pihak ketiga sepanjang pihak ketiga dan pihak lain tersangkut, tidak keluar dari batas hukum, agama dan kesusilaan, juga berlaku mulai dari perkawinan dilangsungkan dan tidak diperbolehkan untuk diubah terkecuali jika ada persetujuan lain dari pasangan suami isteri tersebut dan tidak merugikan pihak manapun.

Perjanjian perkawinan pada awalnya sedikit banyak bertentangan dengan nilai-nilai yang diemban oleh masyarakat kebanyakan. Dahulu pembicaraan mengenai perjanjian perkawinan sangat jarang ditemukan karena masyarakat menganggap bahwa pernikahan merupakan suatu hal yang suci dan sakral maka dari itu masalah harta benda tidak seharusnya dibicarakan sebelum perkawinan berlangsung, padahal masalah mengenai

${ }^{3}$ Indonesia, Undang-undang Nomor 1 Tahun 1974 tentang Perkawinan (Lembar Negara Republik Indonesia Tahun 1974 Nomor 1, Tambahan Lembar Negara Republik Indonesia Nomor 3019), Pasal 29. 
harta benda dan perjanjian perkawinan sangat penting untuk dibicarakan calon pasangan suami istri sebagai persiapan untuk kepentingan saat nanti sudah masuk kedalam kehidupan berumah tangga.

Seiring berjalannya waktu, perjanjian kawin mulai dirasa sebagai suatu hal yang harus dipertimbangkan oleh para calon mempelai. Biasanya perjanjian perkawinan mulai diperbincangkan karena adanya issue dalam financial, misalnya saja calon istri yang memiliki lebih banyak usaha dibandingkan sang suami yang hanya karyawan atau misalnya pekerjaan suami memiliki resiko yang besar terhadap harta kekayaan kedepannya. Adanya keseimbangan maupun perbedaan diantara harta kekayaan suami dan harta kekayaan istri itu yang mendorong mereka untuk melindungi hartanya masing-masing dalam perkawinan. Dorongan itu yang membuat mereka akhirnya merasa penting dan butuh untuk membuat suatu perjanjian perkawinan.

Menurut "UU Perkawinan", jika suatu perjanjian perkawinan ingin dinyatakan sah, maka perjanjian perkawinan tersebut harus didaftarkan dan kemudian harus dikatakan sah oleh pihak-pihak yang memiliki kewenangan didalam hal tersebut yaitu pegawai pencatatan perkawinan. Pasal 29 Ayat (1) mengatakan bahwa sepasang calon suami dan istri diperbolehkan untuk membuat suatu perjanjian perkawinan secara tertulis dengan adanya persetujuan bersama pada saat perkawinan berlangsung atau sebelumya yang nantinya perjanjian tertulis tersebut harus disahkan oleh pihak yang memiliki kewenangan dan isi dari perjanjian tersebut nantinya akan berlaku pula untuk pihak lain selama pihak lain itu memang tersangkut didalam perjanjian tersebut. Hal tersebut merupakan suatu syarat yang harus diberikan perhatian lebih oleh pasangan calon suami istri yang ingin membuat suatu perjanjian kawin, bahwa perjanjian kawin tersebut harus dibuat pada saat mereka melangsungkan perkawinannya atau sebelumnya. Namun pada prakteknya, masih banyak calon mempelai yang akhirnya tidak membuat perjanjian kawin karena beberapa alasan misalnya 
ketidakpahaman bahwa suatu perjanjian kawin harus dibuat pada saat mereka melangsungkan perkawinan atau sebelumnya. Biasanya yang sering terjadi perjanjian perkawinan baru dirasa penting disaat timbul kebutuhan yang memerlukan sebuah perjanjian perkawinan namun hal itu terjadi setelah mereka sudah berada didalam suatu ikatan perkawinan yang sudah berjalan beberapa waktu.

"Perjanjian Perkawinan" biasanya dibuat untuk melindungi kepentingan bisnis dan menghormati nama baik dari pihak-pihak tersangkut. "Perjanjian perkawinan" dapat memberikan kepastian bahwa menikah tidak hanya karena sesuatu hal misalnya harta benda atau warisan yang dimiliki oleh calon pasangan, sehingga niat tulus perkawinan dapat terlihat. Telepas dari hal diatas, terdapat beberapa manfaat dibuatnya perjanjian perkawinan, yakni:

a. Menjamin keamanan bisnis dan urusan usaha

Bila didalam rumah tangga salah satu dari suami istri memiliki usaha atas namanya sendiri, jika dikemudian hari terjadi kerugian, jika pasangan suami istri tersebut didalam perkawinannya tidak memiliki "perjanjian perkawinan" maka kerugian yang ada akan melibatkan kedua suami istri tersebut. Namun jika didalam perkawinannya terdapat "perjanjian perkawinan" maka yang akan dituntut kerugiannya hanya salah satunya saja yang memiliki usaha tersebut. Pasangan nya dapat membantu dan namanya tetap bersih dan tetap cakap hukum.

b. Menjamin keutuhan warisan atau harta yang ditinggalkan keluarga terdahulu

Harta kekayaan yang diturunkan dari keluarga terdahulu itu akan dimiliki atau dikuasai oleh perorangan sesuai yang diputuskan pada awalnya, dengan dibuatkannya "perjanjian perkawinan" akan memastikan bahwa harta atau warisan tersebut tidak akan berpindah kepemilikan karna biasanya yang sering terjadi jika seorang suami atau seorang istri akhirnya meninggal, maka warisan yang sebelumnya ada akan berpindah 
kepada pasangan yang ditinggalkan. Dengan "perjanjian perkawinan" dapat memastikan bahwa warisan tersebut akan tetap turun kepada turunan dari pemilik warisan tersebut jika memang ingin ditentukan demikian.

c. Melindungi hak dari seorang istri jikalau dikemudian hari suami memutuskan untuk menikah lagi (poligami)

Dalam hal poligami yang sah dimana hukum agama, pembuatan "perjanjian perkawinan" akan memastikan bagian-bagian yang sah dan pasti kepada istri-istri yang ada. Hal ini juga dapat menjauhi dari kemungkinan adanya perseteruan dalam menentukan siapa ahli warisnya jika suami meninggal dunia dikemudian hari. Tentunya hal ini dibuat agar setiap istri mendapatkan hak-hak yang adil dan sebagaimana mestinya tanpa menimbulkan suatu masalah terkait harta kekayaan peninggalan suami mereka.

d. Menjamin kondisi financial setelah perkawinan berakhir

Dengan perjanjian perkawinan harta benda akan menjadi milik sendiri, maka jika terjadi putusnya perkawinan harta benda tidak perlu dibagi 2 . Apa yang menjadi hak pemilik, tentu akan tetap menjadi milik sendiri.

e. Menghindari adanya niat lain yang tidak baik

Dengan adanya "perjanjian perkawinan" tentu meyakinkan pasangan bahwa calon suami atau istri menikah bukan karna adanya niat lain yang tersembunyi misalnya ingin menguasai harta dikemudian hari. Jika memang kedua pihak setuju dengan adanya perjanjian kawin maka bisa disimpulkan bahwa memang pernikahan mereka tersebut dilandasi dengan niat yang baik dan tulus.

Di dalam perjanjian perkawinan ada beberapa hal penting yang menjadi syarat dari isi perjanjian perkawinan tersebut. Dalam "Pasal 119" dan "Pasal 139 KUH Perdata" bisa kita simpulkan kalau sebenarnya calon suami dan isteri itu diberikan kebebasan untuk membuat beberapa penyimpangan dari ketentuan mengenai harta perkawinan dengan tidak melebihi atay keluar 
dari batas-batas yang sudah diatur oleh UU sebelumnya. Perjanjian kawin tergolong sebagai suatu bentuk dari perjanjian, sehingga sebuah perjanjian kawin tidak diperbolehkan jika isinya tidak sesuai dengan syarat dari suatu perjanjian, antara lain perjanjian tersebut harus memiliki sebab yang halal yang dimana hal itupun sudah diatur di dalam Pasal 1320 KUH Perdata yang menyatakan bahwa bila sebab tersebut tidak sesuai dengan ketertiban umum dan kesusilaan maka sebab tersebut menjadi tidak diperbolehkan, hal itu diatur dalam KUH Perdata Pasal 1337 yang menyatakan bahwa di dalam perjanjian perkawinan juga dilarang untuk memuat syarat bahwa hak istri akan dihilangkan untuk menolak, memberikan ke orang lain dan mengganti hak dari bagian-bagiannya atas harta bersama tersebut. ${ }^{4}$

Maksud perjanjian perkawinan adalah untuk meberikan aturan-aturan dari akibat-akibat yang mungkin akan timbul didalam ikatan perkawinan terhadap kekayaan dari suami atau isteri juga karena hal-hal tersebut atau ketentuan yang bertujuan lain tidak diperbolehkan. Misalnya, dilarang membuat perjanjian perkawinan jika isinya mengurangi kekuasaan dan hak suami sebagai suami dan orangtua. Menurut P. Scholten, yang termasuk dalam kategori diatas adalah pembebasan istri dari kewajiban untuk bertempat tinggal di tempat suami. ${ }^{5}$

Ketentuan lainnya adalah larangan jika isi perjanjian perkawinan tersebut memuat pernyataan bahwa mereka melepaskan hak-hak mereka atas warisan keluarga mereka maupun mengatur mengenai warisan tersebut. Ketentuan tersebut diatur didalam Pasal 141 KUH Perdata. Pasal tersebut sesuai dengan asas yang termuat dalam "Pasal 1063 KUH Perdata", yang mengatakan jika sekalipun dengan perjanjian perkawinan, suami atau istri tidak diperbolehkan untuk melepaskan hak dan kewajiban dari suatu warisan seseorang yang masih hidup ataupun memindahtangankan hakhaknya atas warisan tersebut dikemudian hari. Terdapat juga asas yang

${ }^{4}$ J. Satrio, Hukum Harta Perkawinan, (Bandung: PT Citra Aditya Bakti, 1993), 157.

${ }^{5}$ Ibid.,158. 
terdapat didalam "Pasal 1334 KUH Perdata", yang berbunyi hal yang baru ada atau yang akan baru ada dikemudian hari di masa yang akan datang, dapat dijadikan hal pokok dari suatu perjanjian. Namun, suami atau istri tidak tidak boleh melepaskan warisan tersebut jika warisan tersebut belum ditentukan, atau juga tidak diperbolehkan untuk menentukan sendiri ketentuan yang akan ada didalam warisan tersebut walaupun dengan persetujuan dari pewaris yang memiliki harta dari warisan tersebut.

Berkaitan dengan kejadian-kejadian tersebut ditas, dalam perjanjian perkawinan ini, pada bulan Oktober tahun 2016 lalu tepatnya pada tanggal 27, Mahkamah Konstitusi RI mengadakan suatu putusan terkait dengan aturan dalam membuat suatu perjanjian perkawinan, yaitu Putusan Mahkamah Konstitusi RI Nomor 69/PUU-XIII/2015. Mahkamah Konstitusi sendiri merupakan salah satu pelaku dari suatu kekuasaan kehakiman dimana hal tersebut juga sudah diatur didalam UUD 1945. ${ }^{6}$ Dalam membentuk MK disetiap negaranya pasti memiliki latar belakang yang berbeda-beda, namun jika dilihat dari segi secara umum, dalam membentuk Mahkamah Konstitusi pasti berawal dari suatu proses atau suatu perubahan politik yang otoriter yang dalam proses tersebut sedan menuju kepada suatu bentuk demokrasi. Mahkamah Konstitusi ini sendiri memiliki 9 anggota yang sebelumnya diajukan oleh MA sebanyak 3 orang, DPR sebanyak 3 orang dan Presiden sebanyak 3 orang, yang nantinya kesembilan anggota tersebut akan ditetapkan oleh Presiden sebagai hakim konstitusi.

Mengenai putusan MK dalam melakukan uji materiil terhadap "Pasal 29 ayat (1), (3), dan (4) UU Perkawinan yang didalam pasal tersebut mengatur mengenai perjanjian kawin. Mahkamah Konstitusi kewenangannya lebih berkenaan dengan lembaga pengadilan hukum. ${ }^{7}$ MK memiliki kewenangan yang berdasarkan kepada prinsip check and

\footnotetext{
${ }^{6}$ Indonesia, Undang-Undang Nomor 24 Tahun 2003 tentang Mahkamah Konstitusi (Lembaran Negara Republik Indonesia Tahun 2003 Nomor 98, Tambahan Lembaran Negara Republik Indonesia Nomor 4316), Pasal 1.

${ }^{7}$ Ni Matul Huda, Hukum Tata Negara Indonesia, (Jakarta: Rajawali Pers, 2014), 213.
} 
Veren Abigail \& Abdul Gani Abdullah PERJANJIAN DALAM PERKAWINAN MENURUT PUTUSAN MAHKAMAH KONSTITUSI RI NO. 69/PUU-XIII/2015 DAN

PENETAPAN PENGADILAN NEGERI TANGERANG NO.269/PEN.PDT.P/2015/PN.TNG

balance dimana kewenangan MK ini akan memberikan keseimbangan bagi semua lembaga negara sehingga memiliki kedudukan yang setara dalam penyelenggaraan negara. Keberadaan MK ini merupakan kiat yang sangat nyata agar penyelenggara negara dapat saling memeriksa kinerja antar lembaga Negara didalam menjalankan pemerintahan yang berdaulat. Sesuai amanat dari Pasal 24C UUD 1945 dibentuklah "Undang-Undang Nomor 24 Tahun 2003" tentang Mahkamah Konstitusi (UU MK). Salah satu isinya adalah mengenai kewenangan yang diberikan kepada MK yang juga salah satunya adalah untuk melakukan pengujian UU secara materiil terhadap Undang-Undang Dasar (UUD). Kewenangan Mahkamah Konstitusi ini biasa dikenal atau disebut Judical Review, yaitu pengujian yudisial atau hak uji materiil. Kewenangan MK ini merupakan kewenangan dalam menilai UU yang mungkin dilihat bertentangan dengan UUD 1945 atau untuk melihat apakah UU tersebut dapat diuji secara yudisial sehingga dinyatakan bertentangan dengan UUD 1945 yang berarti tidak memiliki kekuatan hukum yang mengikat.

Di dalam hal untuk mengajukan uji materiil, putusan MK merupakan putusan final yaitu yang pertama dan yang terakhir. Dalam hal putusan Mk ini tidak ada lagi upaya hukum yang bisa dilakukan atas putusan MK tersebut, maka setiap pihak yang ada didlama perkara tersebut tentu langsung terikat. Kewenangan MK didalam pengujian UU memiliki kelebihan yaitu salah satunya adalah putusan MK memberikan rasa keadilan bagi setiap warga negara yang merasa hak atau kepentingan hukumnya yang telah diakui oleh UUD 1945 dilanggar oleh suatu UU.

Jika berbicara mengenai kewenangan Mahkamah Konstitusi dalam mengadakan uji materil, maka tidak kalah penting yang harus dibahas adalah peran atau kekuasaan hakim itu sendiri sebagai salah satu bagiannya. Hakim adalah salah satu anggota dari Catur Wangsa Penegak Hukum di Indonesia. Seorang hakim memiliki beberapa kewajiban yang paling penting yaitu menerima, memeriksa, memutuskan dan menyelesaikan 
semua perkara-perkara yang diberikan kepada hakim tersebut. Maka hakim dikatakan pelaksana inti dalam penegakkan hukum. Keberadaan hakim pun menjadi sangat penting dalam menegakkan hukum tersebut dan untuk menciptakan suatu keadilan melalui putusan yang dikeluarkannya.

Para warga negara yang mencari suatu keadilan tentu sangat menginginkan setiap perkara yang diajukan dapat berakhir dengan suatu putusan yang mengandung legal justice,moral justice dan juga social justice. Hal ini tentu sulit bagi hakim karena sebagai hakim didalam memutuskan suatu perkara, putusan tersebut harus berisikan 3 hal pokok yaitu kemanfaatan, keadilan, dan kepstian hukum. ${ }^{8}$ Mochtar Kusumaatmadja mengemukakan bahwa seorang hakim didalam memutus suatu perkara, tidak boleh terkena campur tangan masyarakat, maupun eksekutif dan legislatif. ${ }^{9}$ Maka, Hakim didalam memutus suatu perkara putusannya harus sesuai dengan payung hukum pada saat itu dan juga harus berdasarkan kepada keyakinan yang paling adil serta memberikan manfaatmanfaat yang berguna bagi kesejahteraan masyarakat.

Kembali kepada "perjanjian perkawinan", didalam pengaturan perjanjian perkawinan tersebut jika sebelumnya dalam Pasal 29 UU Perkawinan menentukan bahwa "perjanjian perkawinan" harus dibuatkan pada saat perkawinan berlangsung atau sebelumnya, sekarang setelah dikeluarkannya Putusan Mahkamah Konstitusi Nomor 69/PUU-XIII/2015 tersebut, perjanjian perkawinan dapat juga dibuat selama ikatan perkawinan berjalan kapanpun perjanjian kawin itu dirasa dibutuhkan. Hal tersebut berdasarkan dengan pernyataan yang ada didalam Putusan Mahkamah Konstitusi yaitu pasal 29 ayat (1) Undang-Undang Nomor 1 tahun 1974 tentang Perkawinan bertentangan dengan Undang-Undang dasar republik Indonesia Tahun 1945 sepanjang tidak dimaknai "Pada waktu, sebelum

\footnotetext{
8 Ibid., 9.

${ }^{9}$ Mochtar Kusumaatmadja, Fungsi Dan Perkembangan Hukum Dalam Pembangunan Nasional, (Bandung: Bina Cipta, 1986), 320.
} 
Veren Abigail \& Abdul Gani Abdullah

dilangsungkan atau selama dalam ikatan perkawinan kedua belah pihak atas persetujuan bersama dapat mengajukan perjanjian tertulis yang disahkan oleh pegawai pencatat perkawinan atau notaris, setelah mana isinya berlaku juga terhadap pihak ketiga sepanjang pihak ketiga tersangkut”. Pasal 29 ayat (1) Undang-Undang Nomor 1 Tahun 1974 tentang Perkawinan juga dinyatakan tidak mempunyai kekuatan hukum mengikat sepanjang tidak dimaknai "Pada waktu, sebelum dilangsungkan atau selama dalam ikatan perkawinan kedua belah pihak atas persetujuan bersama dapat mengajukan perjanjian tertulis yang disahkan oleh pegawai pencatat perkawinan atau notaris, setelah mana isinya berlaku juga terhadap pihak ketiga sepanjang pihak ketiga tersangkut"10

Sebelumnya pasal 29 ayat (3) UU Perkawinan sudah menentukan bahwa perjanjian perkawinan hanya berlaku sejak saat perkawinan itu dilangsungkan sampai seterusnya, yang akhirnya setelah dikeluarkannya Putusan MK tersebut, perjanjian perkawinan menjadi dapat berlaku kapanpun yang ditetapkan didalam perjanjian perkawinan tersebut.

Sebelumnya pada perjanjian perkawinan tidak ada ketentuan mengenai apa saja isi didalam perjanjian perkawinan tersebut, namun setelah dikeluarkannya Putusan MK tersebut diperjelas bahwa perjanjian perkawinan dapat mengenai harta perkawinan atau perjanjian lainnya, lalu jika sebelumnya juga dalam "perjanjian perkawinan" dinyatakan bahwa perjanjian perkawinan tersebut tidak dapat diubah terkecuali kedua pihak setuju untuk mengubahnya dan perubahan tersebut tidak merugikan siapapun dan pihak manapun, maka kini dalam perjanjian perkawinan telah dinyatakan bahwa tidak hanya perjanjian perkawinan tersebut dapat diubah melainkan dapat juga dicabut sepanjang disepakati bersama dan tidak merugikan pihak manapun.

\footnotetext{
${ }^{10}$ Mahkamah Konstitusi Republik Indonesia, Putusan No. 69/PUU-XIII/2015, 156.
} 
Veren Abigail \& Abdul Gani Abdullah

Setelah melihat perbandingan dari perjanjian perkawinan sebelum adanya uji materiil dan setelah keluarnya Putusan Mahkamah Konstitusi Nomor 69/PUU-XIII/2015 dapat dikatakan bahwa Putusan MK ini memberikan perubahan dan perkembangan yang baik dalam hukum perkawinan yaitu mengenai Perjanjian Perkawinan. Hal ini tentu memudahkan pasangan suami isteri yang membutuhkan peran perjanjian perkawinan disepanjang perkawinannya, karena sebelumnya menurut UU Perkawinan, perjanjian perjawinan itu hanya dapat dibuat pada waktu perkawinan mereka dilangusngkan atau bahkan sebelumnya. Dengan demikian, pembuatan perjanjian kawin disepanjang ikatan perkawinan tidak lagi bertentangan.

Sebelum ditetapkannya Putusan Mahkamah Konstitusi Nomor 69/PUUXIII/2015 tidak jarang juga ditemukan pengesahan perjanjian kawin sepanjang perkawinan, padahal sebelumnya jika berpegang pada UU Perkawinan tentu hal ini tidak seharusnya terjadi. Biasanya hal ini didasari oleh beberapa alasan seperti kealpaan sepasang calon suami isteri mengenai waktu yang sah kapan perjanjian kawin dapat dibuat atau sebelumnya merasa bahwa perjanjian kawin belum dibutuhkan didalam perkawinan mereka. Contohnya adalah Penetapan Pengadilan Negeri Tangerang Nomor 269/PEN.PDT.P/2015/PN.TNG yang isi nya mengenai penetapan perjajian kawin yang dibuat sepanjang perkawinan. Hal ini terjadi tentu karena adanya pertimbangan hakim yang pada akhirnya memberikan penetapan terhadap perjanjian perkawinan itu. Namun perjanjian perkawinan itu ditetapkan sebelum adanya Putusan Mahkamah Konstitusi Nomor 69/PUUXIII/2015 yang berarti penetapan perjanjian perkawinan tersebut berdasar kepada "Pasal 29 ayat (1) UU Perkawinan". Hal ini tentu saja menjadi menarik untuk dibahas lebih lanjut karena seperti yang sudah dijabarkan sebelumnya, bahwa "Pasal 29 ayat (1) UU Perkawinan" menyatakan bahwa pembuatan perjanjian kawin itu pada saat perkawinan berlangsung atau bahkan sebelumnya. Dengan begitu, dapat disimpulkan bahwa penetapan 
Veren Abigail \& Abdul Gani Abdullah PERJANJIAN DALAM PERKAWINAN MENURUT PUTUSAN MAHKAMAH KONSTITUSI RI NO. 69/PUU-XIII/2015 DAN

PENETAPAN PENGADILAN NEGERI TANGERANG NO.269/PEN.PDT.P/2015/PN.TNG

perjanjian perkawinan dalam Penetapan Pengadilan Negeri Tangerang No 269/PEN.PDT.P/2015/PN.Tng ini tidak diputus berdasarkan sebagaimana hukum nya mengatur.

\section{B. Rumusan Masalah}

Setelah melihat latar belakang tersebut, maka muncullah permasalahan yaitu bagaimana pertimbangan hakim dalam mengesahkan perjanjian perkawinan sepanjang perkawinan berlangsung sebelum Putusan Mahkamah Konstitusi RI nomor 69/PUU-XIII/2015 dalam Putusan Penetapan Pengadilan Negeri Tangerang Nomor 269/PEN.PDT.P/2015/PN.TNG.

\section{Metode Penelitian}

1. Jenis Penelitian

Penelitian ini adalah penelitian hukum normatif dimana hokum diletakkan sebagai sebuah bangunan dari suatu sistem norma. Pada penulisan ini menggunakan bahan hukum seperti; Kitab UndangUndang Hukum Perdata, Undang-Undang Republik Indonesia Nomor 1 Tahun 1974 tentang Perkawinan, Putusan Mahkamah Konstitusi Republik Indonesia Nomor 69/PUU-XIII/2015.

2. Sifat Penelitian

Penulisan ini tergolong dalam preskriptif yaitu penelitian yang tujuannya adalah untuk menggambarkan atau merumuskan permasalahan sesuai dengan fakta yang ada pada saat itu.

3. Jenis dan Teknik Pengumpulan Data

Data yang terkumpul merupakan data kualitatif yaitu pengumpulan data penelitian yang bersifat deskriptif dan cenderung menggunakan analisis.

Data yang digunakan dalam penelitian ini adalah data sekunder yang terbagi menjadi 3 yaitu: 
Veren Abigail \& Abdul Gani Abdullah PERJANJIAN DALAM PERKAWINAN MENURUT PUTUSAN MAHKAMAH KONSTITUSI RI NO. 69/PUU-XIII/2015 DAN

PENETAPAN PENGADILAN NEGERI TANGERANG NO.269/PEN.PDT.P/2015/PN.TNG

a. Bahan Hukum Primer

Yakni bahan hukum yang mempunyai otoritas. Terdiri dari perundang-undangan, catatan-catatan resmi atau risalah dalam pembuatan perundang-undangan dan putusan-putusan hakim. ${ }^{11}$ Dalam penulisan ini yaitu:

a) Kitab Undang-Undang Hukum Perdata;

b) Undang-Undang Republik Indonesia Nomor 1 Tahun 1974 tentang Perkawinan;

c) Undang-Undang Republik Indonesia Nomor 24 Tahun 2003 tentang Mahkamah konstitusi;

d) Putusan Mahkamah Konstitusi Republik Indonesia Nomor 69/PUU-XIII/2015;

e) Putusan Penetapan Pengadilan Negeri Tangerang Nomor 269/PEN.PDT.P/2015/PN.TNG.

b. Bahan Hukum Primer

Yakni data yang diperoleh dari semua publikasi tentang hukum yang bukan merupakan dokumen-dokumen resmi. Meliputi bukubuku teks, kamus-kamus hukum, jurnal-jurnal hukum, dan komentar-komentar atas putusan pengadilan. ${ }^{12}$

c. Bahan Non-Hukum

Yakni data non hukum yang dapat memberikan petunjuk atau penjelasan mengenai penelitian tersebut yang dapat berupa: bukubuku, laporan-laporan, jurnal-jurnal non hukum. Dalam penelitian ini bahan non hukum yang digunakan adalah kamus yaitu Kamus Besar Bahasa Indonesia (KBBI).

Teknik pengumpulan data dalam penulisan ini menggunakan studi kepustakaan yang penelitiannya menekankan pada penggunaan data

${ }^{11}$ Peter Mahmud Marzuki, Penelitian Hukum, (Jakarta: Prenadamedia Group, 2005), 133.

${ }^{12}$ Ibid. 
Veren Abigail \& Abdul Gani Abdullah PERJANJIAN DALAM PERKAWINAN MENURUT PUTUSAN MAHKAMAH KONSTITUSI RI NO. 69/PUU-XIII/2015 DAN

PENETAPAN PENGADILAN NEGERI TANGERANG NO.269/PEN.PDT.P/2015/PN.TNG

sekunder, di mana pada waktu penelitian dimulai data telah tersedia seperti buku-buku hukum, naskah dan dokumen hukum.

4. Pendekatan

Pendekatan yang digunakan adalah pendekatan UU dan kasus. Pendekatan UU dilakukan dengan menganalisis semua UU dan regulasi yang bersangkutan dengan suatu isu hukum yang sedang diteliti. ${ }^{13}$ Pada penelitian ini UU yang digunakan adalah UU Perkawinan dan UU Mahkamah Konstitusi.

Pendekatan kasus dilakukan dengan cara melakukan analisis terhadap kasus-kasus yang berkaitan dengan isu yang dihadapi yang sudah memiliki putusan di pengadilan yang berkekuatan hukum tetap.

14 Pada penulisan ini kasus yang di analisis adalah Putusan Penetapan Pengadilan Negeri Tangerang Nomor 269/PEN.PDT.P/2015/PN.TNG.

\section{Teknik Analisis Data}

Penulisan ini menggunakan teknik analisis data deduktif yaitu metode analisis data yang dimulai dari dalil umum dan paradigma tertentu lalu kemudian dihubungkan dengan beberapa data empiris sebagai pokok pengambilan kesimpulannya. ${ }^{15}$

\section{PEMBAHASAN}

\section{A. Perbedaan Pengaturan Perjanjian Perkawinan Pada UU Perkawinan Sebelum dan Sesudah Uji Materiil Dalam Putusan Mahkamah Konstitusi Nomor 69/PUU-XIII/2015}

Perbedaan mengenai pengaturan perjanjian perkawinan memang terjadi setelah adanya uji materiil terhadap "Pasal 29 ayat (1), (3), dan (4) UU Perkawinan" yang mengatur mengenai Perjanjian Perkawinan. Uji materiil ini dilakukan karena terdapat beberapa pasangan suami isteri yang

${ }^{13}$ Peter Mahmud Marzuki, Op. Cit., 181.

${ }^{14}$ Ibid., 134.

${ }^{15}$ Moh. Kasiram, Metodologi Penelitian, (Malang: Uin Maliki, 2010), 130. 
tidak dapat membuat suatu perjanjian yaitu perjanjian kawin setelah pasangan tersebut sudah berada didalam suatu ikatan perkawinan. Hal itu tentu didasari karena ketidaktauan dan ketidakpahaman bahwa ada waktu yang sudah ditentukan oleh UU kapan seharusnya "perjanjian perkawinan" tersebut dibuat.

Sebelum putusan Mahkamah Konstitusi, "perjanjian perkawinan" hanya dapat dibuat pada hari perkawinan atau sebelumnya. Maka dapat disimpulkan bahwa sepasang calon suami dan istri harus membuat terlebih dahulu perjanjian perkawinan sebelum menikah atau paling lambat pada hari pernikahan mereka. Hal ini tentu memberikan batas terhadap waktu pembuatan "perjanjian perkawinan" yang harus ditaati.

Setelah putusan Mahkamah Konstitusi dikeluarkan, terdapat beberapa perubahan terhadap waktu pembuatan perjanjian kawin. Sebelumnya hanya dapat dibuat pada hari perkawinan atau sebelumnya, menjadi dapat dibuat pula sepanjang perkawinan itu berlangsung. Hal ini tentu membuat perubahan yang cukup besar terdapat perjanjian perkawinan di Indonesia. Terhadap perubahan ini dapat kita simpulkan bahwa "perjanjian perkawinan" saat ini sudah dapat dibuat kapanpun selama memang terdapat persetujuan dari suami istri tersebut dan tidak memberikan kerugian kepada pihak manapun selama pihak tersebut tersangkut.

Perbedaan yang terjadi sudah cukup jelas, dapat disimpulkan bahwa sebelum putusan mahkamah konstitusi dikeluarkan, setiap pasangan calon mempelai tidak diperbolehkan membuat perjanjian kawin selain pada waktu yang ditentukan lama dalam "UU Perkawinan Pasal 29 ayat (1)" yaitu pada saat perkawinan berlangsung atau sebelumnya. Berbeda dengan setiap perkawinan yang terjadi setelah putusan Mahkmah Konstitusi, setiap pasangan suami isteri diperkenankan membuat perjanjian kawin kapanpun selama merasa dibutuhkan. Ketentuan-ketentuan lain perjanjian perkawinan tetap harus dierhatikan yaitu dalam ayat (3) dan (4) yang 
Veren Abigail \& Abdul Gani Abdullah PERJANJIAN DALAM PERKAWINAN MENURUT PUTUSAN MAHKAMAH KONSTITUSI RI NO. 69/PUU-XIII/2015 DAN

PENETAPAN PENGADILAN NEGERI TANGERANG NO.269/PEN.PDT.P/2015/PN.TNG

mengatur mengenai kapan perjanjian perkawinan tersebut berlaku dan ketetuan mengenai perubahan pada perjanjian perkawinan tersebut.

Dalam permasalahan yang diangkat saat ini jelas dapat dilihat bahwa putusan penetapan Pengadilan Negeri Tangerang Nomor 269/PEN.PDT.P/2015/PN.TNG tidak diputus sebagaimana hukumnya mengatur. Para pemohon telah menikah selama 16 Tahun lalu membuat permohonan penetapan perjanjian kawin mengenai pemisahan harta kekayaan. Hal ini terjadi sebelum adanya putusan MK yang akhirnya memperbolehkan perjanjian kawin itu dapat dibuat disepanjang ikatan perkawinan, maka seharusnya permohonan penetapan tersebut tidak dapat dikabulkan. Karena sudah jelas pada saat itu, "UU Perkawinan dalam Pasal 29 ayat (1)" menyatakan bahwa perjanjian kawin dapat dibuat dengan persetujuan bersama antara calon suami isteri pada saat perkawinan atau sebelumnya. Maka jelas bahwa hukum yang berlaku saat itu tidak membenarkan pembuatan perjanjian perkawinan disepanjang ikatan perkawinan.

\section{B. Pertimbangan Hakim Dalam Pengesahan Perjanjian Perkawinan Pada}

\section{Putusan Penetapan Pengadilan Negeri Tangerang Nomor 269/PEN.PDT.P/2015/PN.TNG}

Dalam putusannya Hakim memberikan pertimbangannya didalam memutuskan penetapannya tersebut. Dalam putusan ini, Hakim mengatakan bahwa Pasal 29 ayat (1) UU Perkawinan mengatur mengenai "perjanjian perkawinan" hanya dapat dibuat pada saat perkawinan berlangsung atau sebelumnya. Lalu menurutnya bagaimana dengan perjanjian perkawinan yang dibuat setelah perkawinan? apakah tidak diperbolehkan oleh UU Perkawinan?

Hakim menimbang bahwa dalam Pasal 29 ayat (4) dikatakan bahwa perjanjian kawin dimungkinkan untuk dirubah bila ada persetujuan dari kedua pihak dan tidak merugikan pihak ketiga. Hal ini tentu keliru, bunyi 
dari pasal 29 ayat (4) adalah "Selama perkawinan berlangsung perjanjian tersebut tidak dapat diubah, kecuali bila dari kedua pihak ada persetujuan untuk merubah dan perubahan tidak merugikan pihak ketiga." Hal ini jelas bahwa yang dimaksudkan adalah ketika "perjanjian perkawinan" sudah dibuat lalu dikemudian hari ingin dirubah maka diperbolehkan jika ada kesepakatan kedua pihak (suami isteri) dan tidak merugikan pihak manapun selama tersangkut. "Pasal 29 ayat (4)" ini tentu tidak dapat dijadikan dalil dalam mengesahkan suatu perjanjian kawin selama perkawinan berlangsung. Hal ini juga dikemukakan oleh Ibu Cut Memi dalam wawancara yang telah dilakukan sebelumnya, selaku Dosen Ilmu Perundang-undangan Universitas Tarumanagara, Ibu Cut Memi menyatakan bahwa memang "Pasal 29 ayat (4)" ini tidak dapat dijadikan dalil dalam Hakim mengesahkan perjanjian perkawinan sepanjang perkawinan itu berlangsung, yang dimaksud diubah dalam Pasal 29 ayat (4) ini adalah isi dari perjanjian kawin yang sebelumnya sudah dibuat terlebih dahulu, bukan mengubah waktu pembuatan perjanjian perkawinan tersebut.

Pertimbangan Hakim lain adalah dikatakan bahwa tidak ada pasal lain yang melarang tentang dilakukannya perjanjian perkawinan setelah perkawinan dilangsungkan. Padahal sudah jelas dalam "Pasal 29 ayat (1)" dikatakan bahwa perjanjian perkawinan dibuat pada waktu perkawinan dilangsungkan atau sebelumnya. Ketentuan ini tentu bersifat mutlak, bahwa perjanjian perkawinan hanya dapat dibuat dikedua waktu tersebut, tidak dapat diluar waktu itu. Walaupun tidak ditulis langsung, namun kesimpulan dari ayat tersebut sudah dapat menjelaskan kapan perjanjian perkawinan itu dibuat. Pertimbangan Hakim ini merupakan pertimbangan yang sangat keliru. Karena ketentuannya sudah sangat jelas didalam Pasal 29 ayat (1).

Pada pertimbangannya, Hakim juga mengatakan bahwa telah dikenal adanya perjanjian kawin setelah perkawinan dilangsungkan dalam Pasal 139 KUH Perdata. Jika melihat isinya, Pasal 139 KUH Perdata berbunyi: "Para calon suami isteri dengan perjanjian kawin dapat menyimpang dari 
Veren Abigail \& Abdul Gani Abdullah

PERJANJIAN DALAM PERKAWINAN MENURUT

PUTUSAN MAHKAMAH KONSTITUSI RI

NO. 69/PUU-XIII/2015 DAN

PENETAPAN PENGADILAN NEGERI TANGERANG

NO.269/PEN.PDT.P/2015/PN.TNG

peraturan undang-undang mengenai harta bersama asalkan hal itu tidak bertentangan dengan tata susila dan tata tertib umum." Sebelumnya yang harus kita lihat kembali pertama-tama ialah kalimat pertama dalam pasal ini yaitu 'calon suami istri' maka sudah jelas bahwa perkawinan belum berlangsung. Kedua, pasal ini mengatakan bahwa "calon suami isteri dengan perjanjian kawin dapat menyimpang dari peraturan undang-undang mengenai harta bersama' maka yang dimaksud dalam hal ini adalah isi dari perjanjian kawin tersebut yang dapat menyimpang dari ketentuan dari peraturan UU yang mengatur mengenai kentuan dalam pengaturan harta bersama didalam suatu perkawinan.

Undang-undang mengenai harta bersama sebelumnya kita ketahui ada didalam Pasal 35 UU Perkawinan yang mengatakan bahwa jika terdapat harta yang didapat disepanjang ikatan perkawinan maka harta kekayaan tersebut akan menjadi milik bersama antara suami dan isteri. Maka maksud dari Pasal $139 \mathrm{KUH}$ Perdata tersebut adalah, isi dari perjanjian perkawinan dapat keluar dari peraturan undang-undang mengenai ketentuan harta bersama karena isi dari perjanjian perkawinan dapat berupa pemisahan harta benda, dimana harta yang milik suami dan isteri menjadi haknya masingmasing, tidak ada pencampuran. Hal ini yang dimaksud bahwa dengan perjanjian kawin dapat menyimpang dari ketentuan UU mengenai pengaturan harta bersama didalam suatu perkawinan. Maka dapat disimpulkan lagi bahwa pertimbangan Hakim ini juga tidak tepat untuk dijadikan dalil dalam pengesahan penetapan perjanjian perkawinan setelah perkawinan berlangsung tersebut.

Hakim sebagai penegak hukum memang akan mendapatkan perhatian dari masyarakat terkait dengan putusan yang dikeluarkannya karena putusan hakim tersebut beberapa pertimbangannya suka tidak dapat diterima oleh ranah hukum dan terkadang tidak seturut dengan ketentuan-ketentuan hukum yang sebelumnya telah disepakati bersama yang akhirnya berpengaruh terhadap putusan-putusannya. Begitu pula seperti yang 
Veren Abigail \& Abdul Gani Abdullah PERJANJIAN DALAM PERKAWINAN MENURUT PUTUSAN MAHKAMAH KONSTITUSI RI NO. 69/PUU-XIII/2015 DAN

PENETAPAN PENGADILAN NEGERI TANGERANG NO.269/PEN.PDT.P/2015/PN.TNG

dikatakan oleh Bapak Hanafi, Dosen Fakultas Hukum Universitas Tarumanagara, bahwa hakim tidak boleh memutus diluar dari undangundang mengatur, kecuali belum ada undang-undang yang mengatur. Namun pada kasus ini, undang-undang sudah mengatur didalam UU Perkawinan Pasal 29 ayat (1) yang bersifat limitatif, yaitu bersifat membatasi. Karena sudah jelas didalam ayat (1) itu waktu untuk membuat suatu perjanjian kawin adalah pada saat perkawinan berlangsung atau sbelumnya. Ayat (1) tersebut menjadi payung hukum atas ketentuan dalam pembuatan perjanjian kawin pada saat itu, maka putusan Hakim tersebut tidak sejalan dengan hukum yang mengatur saat itu.

Melihat penjelasan diatas, maka dapat dipastikan bahwa penetapan perjanjian perkawinan selama perkawinan berlangusng sebelum putusan Mahkamah Konstitusi Nomor 69/PUU-XIII/2015 dalam Putusan Pengadilan Negeri Nomor 269/PEN.PDT.P/2015/PN.TNG tidak diputus sebagaimana hukumnya mengatur dan pertimbangannya tidak dapat diterima sebagaimana sesuai dengan peraturan yang mengatur. Seharusnya permohonan tersebut tidak dapat dikabulkan mengingat pada saat itu payung hukumnya masih UU Perkawinan Pasal 29 sebelum diuji materiil oleh Mahkamah Konstitusi.

\section{PENUTUP}

A. Kesimpulan

Pertimbangan hakim tidak sebagaimana payung hukumnya mengatur pada saat itu. Dimana pada saat itu "Perjanjian Perkawinan" diatur dalam UU Perkawinan Pasal 29 yang pada ayat (1) dikatakan bahwa Perjanjian Perkawinan hanya dapat dibuat pada saat hari perkawinan atau bahkan sebelumnya. Maka dapat disimpulkan bahwa perjanjian kawin pada saat itu tidak diperbolehkan jika dibuat di sepanjang perkawinan berlangsung. Pasal (4) yang memungkinkan perjanjian kawin dapat diubah selama ada 
persetujuan dari kedua belah pihak, juga tidak dapat dijadikan dalil dalam membuat perjanjian perkawinan disepanjang perkawinan berlangsung, karena yang dimaksudkan diubah didalam ayat tersebut adalah isi dari perjanjian perkawinan, bukan waktu pembuatan perjanjian perkawinan.

Pasal 139 KUH Perdata yang dikatakan Hakim mengatur mengenai pembuatan perjanjian perkawinan selama perkawinan berlangsung juga tidak tepat. Karena di dalam pasal tersebut, hanya mengatakan bahwa calon suami isteri dengan perjanjian perkawinan dapat menyimpang dari ketentuan undang-undang mengenai harta bersama. Dalam hal ini, undangundang mengenai harta bersama ialah UU Perkawinan Pasal 35 yang menyatakan bahwa segala harta yang didapat disepanjang ikatan perkawinan akan menjadi harta milik bersama, karena dengan perjanjian perkawinan, pasangan suami isteri dapat membuat perjanjian yang isinya menyatakan bahwa terdapat pemisahan atas harta kekayaan antara harta suami dan harta isteri selama perkawinan berlangsung.

\section{B. Saran}

Diharapkan hakim sebagai penegak hukum dapat membuat putusan yang sesuai dengan hukum yang mengatur pada saat itu. Karena idealnya putusan hakim harus mengandung 3 hal pokok yaitu: keadilan, kepastian hukum, dan kemanfaatan. Karena hakim adalah pelaksana utama dalam melaksanakan kekuasaan kehakiman, maka peran hakim sangat penting dalam menegakkan hukum dan memberikan keadilan dengan putusanputusannya. Pertimbangan-pertimbangan Hakim juga seharusnya dapat diterima dikalangan hukum, artinya sejalan dengan aturan-aturan hukum dan sesuai dengan payung hukum yang megatur saat itu terkait dengan perkara-perkara yang ditanganinya, sehingga 3 hal pokok tadi dapat terpenuhi dengan sebagaimana mestinya.

\section{DAFTAR PUSTAKA}




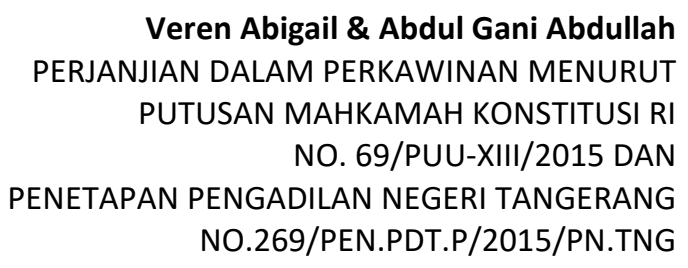

\section{A. Buku}

Damanhuri, H.A. Segi Segi Hukum Perjanjian Perkawinan. Bandung: Mandar Maju. 2007.

Fajar, Mukti dan Yulianto Achmad. Dualisme Penelitian Hukum Normatif dan Empiris. Yogyakarta: Pustaka Pelajar. 2010.

Hadikusuma, Hilman. Hukum Perkawinan Indonesia. Bandung: CV Mandar Maju. 2007.

Huda, Ni Matul. Hukum Tata Negara Indonesia. Jakarta: Rajawali Pers. 2014.

Judiasih, Sonny Dewi. Harta Benda Perkawinan. Bandung: PT Refika Aditama. 2015.

Kasiram, Moh. Metodologi Penelitian. Malang: Uin Maliki. 2010.

Koentjaraningrat. Metode-Metode Penelitian Masyarakat. Jakarta: PT Gramedia. 1983.

Kriyantono, Rachmat. Teknik Praktis Riset Komunikasi. Jakarta: Kencana Preneda Media Group. 2006.

Kusumaatmadja, Mochar. Fungsi Dan Perkembangan Hukum Dalam Pembangunan Nasional. Bandung: Bina Cipta. 1986.

Marzuki, Peter Mahmud. Penelitian Hukum. Jakarta: Prenadamedia Group. 2005.

Muhammad, Abdulkadir. Hukum Perdata Indonesia. Cetakan ke-5. Bandung: PT Citra Aditya Bakti. 2014.

Prins, J. Tentang Hukum Perkawinan di Indonesia. Jakarta: Balai Aksara. 1982.

Prodjodikoro, R. Wirjono. Hukum Perkawinan di Indonesia. Jakarta: Sumur Bandung. 1991.

Ramulyo, Mohd Idris. Dari Segi Hukum Perkawinan Islam. Jakarta: IndHill Co. 1990.

Satrio, J. Hukum Harta Perkawinan. Bandung: PT Citra Aditya Bakti. 1993. 
Veren Abigail \& Abdul Gani Abdullah PERJANJIAN DALAM PERKAWINAN MENURUT PUTUSAN MAHKAMAH KONSTITUSI RI NO. 69/PUU-XIII/2015 DAN

PENETAPAN PENGADILAN NEGERI TANGERANG NO.269/PEN.PDT.P/2015/PN.TNG

Saleh, K. Wantjik. Hukum Perkawinan Indonesia. Jakarta: Ghalia Indonesia. 1980.

Soetojo, Prawirohamidjojo R. Pluralisme dalam Perundang-undangan Perkawinan di Indonesia. Surabaya: Airlangga University Press. 1988. . Hukum Orang dan Keluarga. Surabaya:

Alumi. 2000.

Sosroatmodjo, Arso dan Wasit Aulawi. Hukum Perkawinan di Indonesia. Jakarta: Bulan Bintang. 2001.

Subekti. Pokok-Pokok Hukum Perdata. Jakarta: PT Intermasa. 1985. . Hukum Perjanjian. Jakarta: PT Intermasa. 1990.

Sudarsono. Hukum Perkawinan Nasional. Jakarta: Rineka Cipta. 2010.

Syahrani, Riduan. Rangkuman Intisari Ilmu Hukum.Bandung: Citra Aditya Bakti. 1999.

Syahuri, Taufiqurrohman. Legitimasi Hukum Perkawinan Di Indonesia. Jakarta: Kencana. 2013.

Tutik, Titik Triwulan. Pengantar Hukum Perdata di Indonesia. Cetakan Pertama. Jakarta: Prestasi Pustaka. 2006.

\section{B. Peraturan Perundang-Undangan}

Indonesia. Undang-Undang Tentang Perkawinan, UU No. 1 Tahun 1974. Indonesia. Peraturan Pemerintah tentang Pelaksanaan Undang-Undang Nomor 1 Tahun 1974 Tentang Perkawinan. PP No.9 Tahun 1975.

Kitab Undang-Undang Hukum Perdata [Burgerlijke Wetbook]. Diterjemahkan oleh Subekti dan Tjitrosudibio, cet. 41. Jakarta: PT Balai Pustaka, 2013.

\section{Putusan Pengadilan}

Mahkamah Konstitusi Republik Indonesia. Putusan Nomor 69/PUUXIII/2015. 
Veren Abigail \& Abdul Gani Abdullah PERJANJIAN DALAM PERKAWINAN MENURUT PUTUSAN MAHKAMAH KONSTITUSI RI NO. 69/PUU-XIII/2015 DAN

PENETAPAN PENGADILAN NEGERI TANGERANG NO.269/PEN.PDT.P/2015/PN.TNG

Pengadilan Negeri Tangerang. Penetapan Nomor 269/PEN.PDT.P/2015/PN.Tng.

D. Kamus

Departemen Pendidikan Nasional. Kamus Besar Bahasa Indonesia. Jakarta: Balai Pustaka. 2005.

\section{E. Sumber Lainnya:}

Idtesis, “Idtesis: Penulisan Hukum”, https://idtesis.com/penelitian-hukumdikelompokkan-berdasar-sifat-dan-fokus-kajian/ (Diakses 15 Maret 2019).

The Embassy of Indonesia, "Information of Indonesians", http://www.indonesia.cz/consularvisa-service/tata-cara-mendaftarkanpernikahan-luar-negeri-di-indonesia/ (Diakses 20 April 2019).

Wikipedia Online, “Wikipedia: Penelitian Kualitatif”, www.Wikipedia.org (Diakses 07 Desember 2018).

Wikipedia Online, "Wikipedia: Pernikahan", https://id.wikipedia.org/wiki/Pernikahan (Diakses 08 Desember 2018). 